\section{New APSA Officers Elected}

At the 90th Annual Meeting, the slate of officers put forward by the APSA Nominating Committee was unanimously accepted. The 1994-95 APSA officers are:

President:

Sidney Verba, Harvard University

President-Elect:

Arend Lijphart, University of California, San Diego

Vice-Presidents:

F. Chris Garcia, University of New Mexico

Betty Glad, University of South Carolina

Catherine Kelleher, The Brookings Institution

Treasurer:

Susan Bourque, Smith College

Secretary:

Loch Johnson, University of Georgia

As the newly elected President, Verba made the following appointments to APSA Council Committees for 1994-95:

\section{Administrative Committee:}

Serving with Sidney Verba, President; Arend Lijphart, PresidentElect; and Susan Bourque, Treasurer.

Timothy Cook, Williams College

F. Chris Garcia, University of New Mexico

Mark Hansen, University of Chicago

Toni-Michelle Travis, George Mason University

Elections Committee:

Loch Johnson, University of Georgia

Margaret Levi, University of Washington, Chair

Helen Milner, Columbia University

Rules Committee:

John A. Garcia, University of Arizona

Anne Hopkins, University of Minnesota, Chair
William Nelson, Jr., The Ohio State University

\section{Ada Finifter to be APSR Editor}

At the August 31 Council Meeting presided over by APSA President Charles O. Jones, Ada W. Finifter, Michigan State University, was unanimously approved to be the next Managing Editor of the American Political Science Review. Jones and Council members praised the scholarly and administrative achievements of Finifter and expressed their confidence that she would follow in the exemplary style of the current Managing Editor, G. Bingham Powell, Jr. The editorial transition of the APSR with begin in the summer of 1995 . Finifter will start to receive manuscripts in the fall of 1995 and will publish her first issue of the APSR as Managing Editor in March 1996.

Finifter's name was put forth to the Council by the members of the Managing Editor Search Committee appointed by President Jones. The members of the committee included:

Sidney Verba, Harvard University, Chair

Leon Epstein, University of Wisconsin

Jean Bethke Elshtain, Vanderbilt University

John Hibbing, University of Nebraska, Lincoln

Matthew Holden, University of Virginia

Keith Krehbiel, Stanford University

G. Bingham Powell, Jr., University of Rochester

Kay Schlozman, Boston College

\section{Section News}

\section{APSA Organized Sections Distribute Awards at Annual Meeting}

Twenty-two of the 32 APSA Organized Sections used the $1994 \mathrm{An}$ nual Meeting as an opportunity to recognize distinctive scholarship and career service within their fields of political science.

\section{Federalism and Intergovernmental Relations}

The Distinguished Scholar Award in recognition of distinguished scholarly contributions to the study of federalism and intergovernmental relations was awarded to Samuel $\mathrm{H}$. Beer, Harvard University. The Best Paper Award, conferred upon the best paper in the field of federalism and intergovernmental relations presented at the previous year's annual APSA meeting was presented to Rey Koslowski, University of Pennsylvania.

\section{Law and Courts}

The C. Herman Pritchett Award for the best book in the field of Law and Courts authored by a political scientist in 1993 was awarded to Howard Gillman, University of Southern California, for his book The Constitution Besieged: The Rise and Demise of Lochner Era Police Powers Jurisprudence (Durham: Duke University Press, 1993). Honorable Mention was given to: Kevin T. McGuire, University of Minnesota, for The Supreme Court Bar: Legal Elites in the Washington Community (Charlottesville: University Press of Virginia, 1993).

The American Judicature Society Award for the best faculty paper in the field of Law \& Courts presented at the previous year's APSA Annual Meeting was presented to Christine Harrington, New York University and Daniel Ward, Rice University, for "Rethinking Litigation: The Role of Courts in Produc ing Litigation."

The CQ Press Award for best paper in the field of Law \& Courts by a political science graduate student was won by Nancy Crowe, University of Chicago, for "Gender and Asset Settlements in Divorce Proceedings."

\section{Legislative Studies}

The CQ Press Award for an outstanding paper in legislative politics 